\title{
Risk Preference of Palm Sugar Craftsman in Lebak Regency, Banten
}

\author{
Andjar Astuti \\ Agribusiness Department, Agriculture \\ Faculty \\ University of Sultan Ageng Tirtayasa \\ Serang, Indonesia
}

\author{
Ratna Mega Sari \\ Agribusiness Department, Agriculture \\ Faculty \\ University of Sultan Ageng Tirtayasa \\ Serang, Indonesia \\ ratna.megasari@untirta.ac.id
}

\author{
Suherman \\ Agribusiness Department, Agriculture \\ Faculty \\ University of Sultan Ageng Tirtayasa \\ Serang, Indonesia \\ suhermanuntirta@yahoo.com \\ Asih Mulyaningsih \\ Agribusiness Department, Agriculture \\ Faculty \\ University of Sultan Ageng Tirtayasa \\ Serang, Indonesia \\ asihmulya@ymail.com
}

\author{
Setiawan Sariyoga \\ Agribusiness Department, Agriculture \\ Faculty \\ University of Sultan Ageng Tirtayasa \\ Serang, Indonesia \\ setiawansariyoga@yahoo.com
}

\begin{abstract}
The growth of palm sugar production in Lebak Regency as the center of palm sugar in Banten Province continues to show a positive trend so that it is an important source of income for many households in Lebak Regency. The purpose of this study is to analyze the risk of palm sugar craftsman business which includes production risk and income risk. The research data used are primary and secondary data which are processed descriptively and quantitatively. Quantitative data is processed using variance analysis, deviation standard and coefficient of variation. The results showed the risk of production of the palm sugar business in Lebak Regency had a high coefficient of variation reaching 0.26086 or 26.09 percent, meaning that every single rupiah produced the risks faced were 0.26086 or $26.09 \%$. the risk received by the brown sugar craftsmen in Lebak Regency is 0.4371 or reaches $43.71 \%$ of the income earned by farmers with a deviation standard of 62916.26. craftsmen need to be careful in running a brown sugar business so that the combination of the use of inputs can achieve maximum output and brown sugar businesses achieve efficiency because thus both production risk and revenue risk can be reduced so that the brown sugar business can produce high production and high income. Result of the research also showed that palm sugar craftsman tends to be risk averse.
\end{abstract}

Keywords: palm sugar, business risk, risk preference, lebak regency

\section{INTRODUCTION}

\section{A. Background}

Local economic development through the home industry or small, micro and medium business. sector has a great influence on the national economy.small, micro and medium business contributed $60.34 \%$ to GDP of Indonesia in 2015( Ministry of Industry, 2016). In addition to providing support in economic aspects, this industry also plays a strategic role in developing potential local commodities. One of the leading local commodities that can become a national mainstay is palm sugar.

Palm sugar is a product derived from palm plants. Before being processed into palm sugar, raw materials derived from palm plants are called roomie. Sap is a sweet liquid obtained from palm bunches. Palm sugar can be used as an additional ingredient or flavoring in the food industry such as in making soy sauce and dodol, additives or flavorings in food preparations such as cakes, compote and other food preparations, as well as sweeteners in beverages such as bandrek, bajigur, coffee, and others.

Palm sugar has its own uniqueness The uniqueness of this product, among others, is more soluble, dry and clean and has a distinctive aroma. This characteristic causes palm sugar to be widely used to make cakes, soy sauce and other food products [1]. According to Rumokoi (1990), excess palm sugar compared to other sugars based on chemical composition, namely a higher sukros content of 84.81 percent compared with coconut sugar 71.89 percent and palm sugar 76.86 percent, so that palm sugar can provide higher energy than coconut sugar and palm sugar.

Based on the nutritional content, compared to other sugars, palm sugar contains protein and phosphorus which is higher than coconut sugar and palm sugar. Palm sugar also contains low fat compared to sugar derived from coconut sugar and palm sugar. High protein content and low fat content, shows that palm sugar is better for consumption compared to sugar derived from coconuts and siwalan, especially its health benefits.

Banten is one of the centers of palm sugar production in Indonesia Indonesian Bank (2009). The growth of palm sugar production in Banten Province on average experienced a positive trend. Production of palm sugar from 2009 to 2011 experienced an increasing trend, while in 2012 there was a decline in production of 0.24 percent. This is due to the existence of plants that have decreased productivity, the existence of plants that are not productive and the change of seasons. Whereas in 2013 production increased again by 0.60 percent. However, the growth of palm sugar production in Banten Province for five years starting from 2009 to 2013 on average increased by 0.09 percent each year. This shows that the growth of palm sugar production is very slow, because there is no government support in terms of palm nurseries, intensive cultivation of sugar palm and rejuvenation of palm sugar. 
Palm sugar centers in Banten Province are in the Regency (BPS Kabupaten Lebak 2014). The growth of palm sugar production in Lebak Regency on average experiences a positive trend. Palm sugar production experienced stable growth from 2009 to 2010, but experienced a decline in 2011 which was 81.32 percent, production again increased in 2012 with the highest rate of 523.38 percent. While in 2013 it experienced a decline of 12.63 percent. This is due to the existence of plants that have decreased productivity, the existence of plants that are not productive, and the change of seasons.

Meanwhile, the growth of palm sugar production in Lebak Regency for five years starting from 2009 to 2013 on average increased by 0.35 percent every year. The growth of palm sugar production in Lebak Regency is relatively fast. Lebak Regency has contributed 70 percent of palm sugar in Banten over the past five years. While for the last year of 2013, Lebak contributed 81 percent of palm sugar in Banten. This shows that Lebak Regency has a big role in supplying palm sugar in Banten. (central bureau of statistics of Banten Province, 2014)

Palm sugar production areas in Lebak Regency are spread in 28 sub-districts and the centers are in 15 subdistricts. Palm sugar producing areas include Sobang District, Bojong Manik, Lebak Gedong, Sajira, Gunung Kencana, Cigemblong, Cijaku, Cibeber, Cilograng, Temple, Muncang, Cirinten, Wanassalam, Malingping and Panggarangan District. The amount of palm sugar production in the production center is 12082.35 tons per year. The biggest producer is in Sobang District with a percentage of 21 percent (2505.3 tons per year). The palm sugar includes printed palm sugar and ants.

\section{B. Problem Formulation}

The Prospect of this commodity is increasingly promising because raw material for the production of palm sugar are abundant in supporting the development of small palm sugar industry. Market opportunities that promise large profit and are supported by large raw material show that this industry is potential tobe developedHowever, market opportunities that promise large profits and are supported by large raw materials, have not been able to be utilized by the palm sugar processing industry to the fullest. There are several obstacles that may be faced by palm sugar craftsmen in developing their businesses. Palm sugar producers still seem to have limitations in capital, marketing and the technology used. Furthermore, like businesses in other fields, palm sugar craftsmen will also be faced with. faced not only the price but also the risk of getting tapped sap and production. Departing from the discussion above, the research to explain how the magnitude of the risk of palm sugar business in Lebak Regency and how the risk preferences of palm sugar craftsmen in Lebak Regency.

\section{Research Purpose}

This study aims to analyze the risk of production and the risk preference of palm sugar prices in Lebak Regency

\section{RESEARCH METHODS}

The location of the study was determined by the method of calculating variance, standard deviation and coefficient of variation. The First Stage, selected five Districts in Lebak Regency based on the number of small palm sugar industries.
Furthermore, from each district selected villages with the same selection criteria, the method of determining respondents was carried out using a simple random sampling method (as many as 86 sugar palm craftsmen). Determination of the number of samples is done by using the formula proposed by Sheaffer et al (1990).

The study of palm sugar business patterns is used by using descriptive analysis both quantitatively and qualitatively. Meleong (2004) and Sukandarrumidi (2004), in quantitative descriptive analysis will be presented through a process of codetification, categorization, interpretation, interpretation and abstraction. With this analysis we will get a picture of the variations related to the subject and object of research. Meanwhile, the magnitude of the risk of palm sugar in Lebak Regency was analyzed using the following formula

Expected Results (E) calculate the amount of roomie, production, and averageprice of the expected results with an estimated average value as follows:

$$
E=\frac{\sum E i j}{n t}
$$

where $\mathrm{E}$ is the average roomie, production, and expected price, Eij is the amount of roomie, production and price received by the craftsman $\mathrm{i}$ and the production process to $\mathrm{j}$. The number of respondents was 86 palm sugar craftsmen.

The magnitude of the risk faced by palm sugar craftsmen is estimated statistically by looking at the magnitude of variation and standard deviation. The amount of variance is calculated using the following formula:

Knowing the level of production risk by using quantitative analysis in the form of coefficient of variation analysis. The coefficient of variation analysis is used to determine the level of production risk faced by farmers. The smaller the coefficient of variation, the lower the level of risk faced by farmers, to get the coefficient value of the stages that must be done are as follows:

\section{1) Standard Deviation}

Standard deviation of production output illustrates the difference or difference between production output and expected output. The greater the value of standard deviation, the greater the level of risk faced in production activities. To calculate the standard deviation $(\sigma)$ of a distribution, use the following three-step process:

Each possible result $\left(\mathrm{X}_{\mathrm{i}}\right)$ is reduced by the expected value or mean $((\mathrm{X}))$ distribusi of the distribution to get a series of deviations $\left(\mathrm{d}_{\mathrm{i}}\right)$ of the expected value, namely:

Squeeze each deviation, then add all of them together. The weighted average of the squared deviations is called the variance of the distribution $\left(\sigma^{2}\right)$, namely:

$$
d_{i}=X_{i}-\bar{X}
$$


Calculate the square root of the variance to get the standard deviation of production output can be written as follows:

$$
\sigma^{2}=\sum_{i=1}^{n}\left(X_{i}-\bar{X}\right)^{2}
$$

\section{2) Coefficient variation}

Coefficient variation of output is measured from the ratio of standard deviation of output to expected output. The smaller the coefficient variation, the lower the risk faced by craftsmen Mathematically, the coefficient variation can be written as follows:

$$
\mathrm{CV}=\delta Q / \mathrm{X}_{\mathrm{r}}
$$

Knowing the sources of risk of onion farming by using descriptive analysis. Descriptive analysis is used in this study to describe descriptively the condition of the palm sugar business and the characteristics of the palm sugar craftsmen themselves. Several stages are carried out to obtain the real conditions of the palm sugar business which are described descriptively, namely: Identification of the characteristics of palm sugar craftsmen and Identification of risk sources.

\section{General Description Of Lebak District}

Geographically, Lebak Regency is located at position $105^{\circ} 25^{\prime}-106^{\circ} 30^{\prime}$ East Longitude and $6^{\circ} 18$ '- $7^{\circ} 00^{\prime}$ South Latitude. Lebak Regency has an area of 330,507.16 Ha. While the area of sea area under the authority of Lebak Regency is $73.3 \mathrm{Km}^{2}$ with a coastline length of about 91.42 $\mathrm{Km}^{2} .1$ The boundaries of the Lebak Regency are as follows:

- North side: Serang Regency and Tangerang

- East side: Bogor and Sukabumi Regencies

- West side: Pandeglang Regency 4. South: Indian Ocean

The morphology of Lebak Regency can be divided into hills (sloping, bumpy, steep) and mountains or mountains 3

- Datebar scattered in the north, west and south of Lebak Regency

- Dutch hills are spread in the south and north to the east of Lebak Regency

- Corrugated hills are located in the middle and south to the east of Lebak Regency

- Steep hills are located in the middle to the east of Lebak Regency

Population as one of the components in a regional system has an important role as the subject of changes in the use of space through various activities in order to meet their needs. Aside from being a doer of spatial change, residents are also parties who will benefit from spatial planning efforts. Thus population dynamics have an important role as objects and in the dynamics of the development of a region.

As the subject of development, the potential of human resources is used as the spearhead to accelerate improvements towards a better life. The higher the quality of human resources, the faster the process of improvement will occur. Meanwhile, as an object of development, human resources need attention, because development that only has physical aims, without being accompanied by preparing supporting devices, will only lead to gaps in progress.

\section{Lebak Regency Economy}

Economic growth is one of the indicators used to look at people's welfare from an economic aspect. Economic growth $\mathrm{s}$ also one of the targets in the process of economic development. The success of a country's development can be seen from the rising rate of economic growth in the country.

National economic development cannot be separated from economic development in the regions. Regional economic development is a process in which the regional government and the community manage existing resources by establishing a partnership pattern between the regional government and the private sector in order to create jobs and stimulate economic growth in the area (Arsyad, 2002)

Lebak Regency is one of the regencies in Banten Province which is one of the provinces that had recently experienced a division in the year. Primary sectors such as the agricultural sector are the economic support that is quite high compared to other sectors in Lebak Regency.

\section{Palm Sugar Business in Lebak Regency}

The palm sugar business in Lebak Regency, Banten has not used the concept of a garden. The development of the sugar palm population is spread naturally by ferrets. Palm trees are owned in units of number of trees.

The average age of productive sugar palm plants is 10-15 years which is tapped after the fruit comes out. The productive age of palm trees can reach more than three years with the production of roomie 200 days x 15 liters / day equivalent to 3000 liters / tree / year or $300 \mathrm{~kg}$ of palm sugar / tree / year. A sugar palm farmer in one day is able to tap 56 palm trees. Palm trees that have more than 5 fruit bunches are usually allowed to harvest as many as 1-2 bunches.

\section{Characteristics of Palm Sugar Craftsmen}

All respondents of palm sugar craftsmen are men with the age of palm sugar craftsmen in the range of 35-61 years.

The results showed that the average age of palm sugar craftsmen was around 46 years. This shows that the average age of the craftsmen is still at a productive age. In the opinion of Mubyarto (1989), productive age ranges from 15 65 years. Where at this age palm sugar craftsmen will try to produce maximum work productivity. Viewed from the level of education, the level of formal education varies greatly from not attending school to high school graduates. Respondents of palm sugar craftsmen who never had formal education were 11.76 percent, 5.88 percent graduated elementary school, 7.84 percent graduated junior high school, 74.51 percent graduated high school. This shows that the level of education of palm sugar craftsmen is quite high. Palm sugar craftsmen have business experience in the range of 1-8 years with an average business experience of 4 years. 


\section{Sugar Production Risk Analysis}

Brown sugar craftsmen in Lebak Regency, Banten face several risks in running their businesses. Palm sugar craftsmen do not yet know how much level. Based on the table, it can be seen that the risk of production of the palm sugar business in Lebak Regency has a high coefficient of variation reaching 0.26086 or 26.09 percent, meaning that every single rupiah produced risks faced by 0.26086 or $26.09 \%$. The greater the coefficient of variation of a commodity, the greater the risk to be borne. The high coefficient of production variation results from variations in the amount of sugar palm that can be tapped every time the tapping process.

TABLE I. STANDARD DEVIATION AND VARIATION COEFFICIENT BASED ON PRODUCTION

\begin{tabular}{c|c}
\hline Description & Production Risk \\
\hline average of Production & 1.908846154 \\
Deviation standard & 1.381609986 \\
Variation Coefficient(CV) & 0.260863424 \\
CV $(\%)$ & $26.09 \%$ \\
\hline
\end{tabular}

In addition to assessing risk with production, risk assessment is also carried out using income indicators. Revenue is the value obtained by palm sugar craftsmen from the receipt of sales of production after deducting the costs incurred in conducting palm sugar business. Revenue risk is analyzed using the coefficient of variation (CV) whose results can be seen in the table below.

TABLE II. DEVIATION STANDARD AND VARIATION COEFFICIENT PALM SUGAR CRAFTSMAN BASED ON INCOME IN LEBAK REGENCY $2018 / 2019$

\begin{tabular}{c|c}
\hline Description & Income Risk \\
\hline average of Income & 143940 \\
Deviation standard & 62916.26499 \\
Variation Coefficient(CV) & 0.437100632 \\
CV $(\%)$ & $43.71 \%$ \\
\hline
\end{tabular}

Based on the Table shows seen from the side of palm sugar business revenue, that the risk of palm sugar business revenue in Lebak Regency is quite high, the risk received by the brown sugar craftsmen in Lebak Regency is 0.4371 or reaches $43.71 \%$ of the value of the income obtained by farmers with a standard deviation of 62916.26. Based on research results, both the risk of production and the risk of palm sugar business revenue is quite high. The percentage coefficient of variation (CV) of income risk reaches 43.71 percent so the craftsman needs to be careful in running a brown sugar business so that the combination of the use of inputs can achieve maximum output and brown sugar business reaches efficiency because thus both production risk and income risk can be reduced so that the business brown sugar can produce high production and high income.

\section{RISK PRERERENCES}

the average AR value from weather risk sources is 1.8 . based on this value, it can be explained that the AR value $>0$.
AR value $>0$ can be interpreted that in dealing with weather risk sources, palm sugar craftsman have a risk averse attitude. This risk taker attitude can be interpreted that each craftsman in facing this risk dares to face the risk.

\section{CONCLUSION}

The results showed the risk of production of the palm sugar business in Lebak Regency had a high coefficient of variation reaching 0.26086 or 26.09 percent, meaning that every single rupiah produced the risks faced were 0.26086 or $26.09 \%$. the risk received by the brown sugar craftsmen in Lebak Regency is 0.4371 or reaches $43.71 \%$ of the income earned by farmers with a standard deviation of 62916.26. craftsmen need to be careful in running a brown sugar business so that the combination of the use of inputs can achieve maximum output and brown sugar businesses achieve efficiency because thus both production risk and revenue risk can be reduced so that the brown sugar business can produce high production and high income.

\section{REFERENCES}

[1] Aliudin. 2010. Prospek Gula Aren dalam Agroindustri. Bandung (ID): Unpad Press. Amir IT. 2010. Tingkat Kepuasan dan Kepatuhan Petani Tebu Terhadap Pola Kerjasama dengan Pabrik Gula Gempolkrep. JPM. Vol. 12(2):76-84.

[2] Asmarantaka RW. 2012. Pemasaran Agribisnis (Agrimarketing). Bogor (ID): IPB Press.

[3] [BI] Bank Indonesia. 2009. Pola Pembiayaan Usaha Kecil Syariah (PPUK) Gula Aren (Gula Semut dan Gula Cetak). Jakarta (ID): Bank Indonesia.

[4] [BPS] Badan Pusat Statistik Provinsi Banten. 2010-2014. Banten dalam Angka 2009-2013. Serang (ID): BPS Provinsi Banten.

[5] [BPS] Badan Pusat Statistik Kabupaten Lebak. 2010-2014. Lebak dalam Angka 2009-2013. Lebak (ID): BPS Kabupaten Lebak.

[6] [BPS] Badan Pusat Statistik Kabupaten Pandeglang. 2014-2015. Pandeglang dalam Angka 2013-2014. Pandeglang (ID): BPS Kabupaten Pandeglang.

[7] [BPS] Badan Pusat Statistik Kecamatan Pandeglang. 2014-2015. Kecamatan dalam Angka 2013-2014. Pandeglang (ID): BPS Kabupaten Pandeglang.

[8] Gaynor PE, Kirckpatrick RC. 1994. Introduction to Time-series Modelling and Forecasting in Business and Economics. Mc GrawHill, Inc : Singapura.

[9] Hyman DN. 1996. Microeconomics. New York : McGraw-Hill,Inc

[10] Jorion P.2002. Value at Risk : the new benchmark for managing financial risk, second edition. McGraw-Hill. California. North America.

[11] Kementerian Pertanian. 2015. Keragaan Pembangunan Hortikultura http://hortikultura.pertanian.go.id/ content/uploads/2015/06/BabIII.pdf. Diakses tanggal 11 Juni 2017

[12] Kountur, R. 2004. Manajemen Risiko Operasional (Memahami Cara Mengelola Risiko Operasional Perusahaan. PPM. Jakarta. Lipsey RG, Courant PN, Purvis DD, Steiner PO. 1995. Pengantar Mikroekonomi. Jaka W dan Kirbrandoko, penerjemah; Jakarta: Binarupa Aksara. Terjemahan dari: Economis 10th ed.

[13] McConnel CR, Brue SL. 1990. Microeconomics, Principles, Problems and Policies. New York : McGraw-Hill, Inc

[14] Prajnanta F. 1999. Agribisnis Cabai Hibrida. Penebar Swadaya : Jakarta

[15] Pyndyck RS, Rubinfeld, DL. 1983. Econometric Models And Economic Forecasts. Japan : McGraw-Hill, Inc

[16] Robison, L.J. and P.J Barry. 1987. The Competitive Firm's Response To Risk. Macmillan Publishing Company. New York. 